\title{
Followership and leadership in different sorts of sloyd practices
}

\author{
Marcus Samuelsson \\ Linköping University Post Print
}

Tweet

N.B.: When citing this work, cite the original article.

This is an electronic version of an article published in:

Marcus Samuelsson, Followership and leadership in different sorts of sloyd practices, 2013, Ethnography and Education, (8), 1, 105-117.

Ethnography and Education is available online at informaworldTM:

http://dx.doi.org/10.1080/17457823.2013.766437

Copyright: Taylor \& Francis (Routledge): SSH Titles

http://www.routledge.com/

Postprint available at: Linköping University Electronic Press

http://urn.kb.se/resolve?urn=urn:nbn:se:liu:diva-88488 
This article was downloaded by: [Linköping University Library]

On: 29 March 2015, At: 03:17

Publisher: Routledge

Informa Ltd Registered in England and Wales Registered Number: 1072954 Registered

office: Mortimer House, 37-41 Mortimer Street, London W1T 3J H, UK

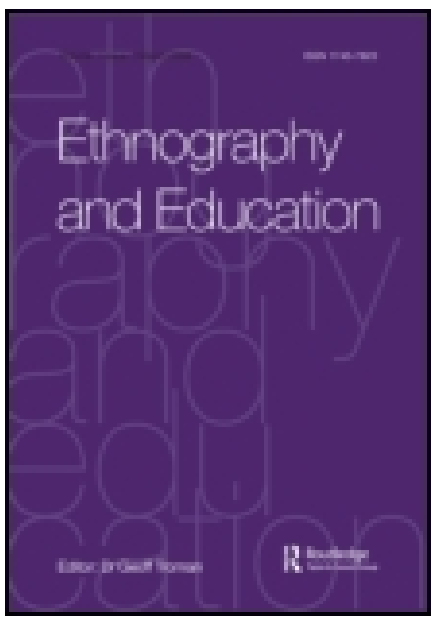

\title{
Ethnography and Education
}

Publication details, including instructions for authors and subscription information:

http:// www.tandfonline.com/loi/ reae20

\section{Followership and leadership in different sorts of sloyd practices}

\author{
Marcus Samuelsson ${ }^{a}$ \\ a Department of Behavioural Science and Learning , Linköping \\ University, Linköping, Sweden \\ Published online: 20 Feb 2013.
}

To cite this article: Marcus Samuelsson (2013) Followership and leadership in different sorts of sloyd practices, Ethnography and Education, 8:1, 105-117, DOI: 10.1080/17457823.2013.766437

To link to this article: http:// dx.doi.org/ 10.1080/ 17457823.2013.766437

\section{PLEASE SCROLL DOWN FOR ARTICLE}

Taylor \& Francis makes every effort to ensure the accuracy of all the information (the "Content") contained in the publications on our platform. However, Taylor \& Francis, our agents, and our licensors make no representations or warranties whatsoever as to the accuracy, completeness, or suitability for any purpose of the Content. Any opinions and views expressed in this publication are the opinions and views of the authors, and are not the views of or endorsed by Taylor \& Francis. The accuracy of the Content should not be relied upon and should be independently verified with primary sources of information. Taylor and Francis shall not be liable for any losses, actions, claims, proceedings, demands, costs, expenses, damages, and other liabilities whatsoever or howsoever caused arising directly or indirectly in connection with, in relation to or arising out of the use of the Content.

This article may be used for research, teaching, and private study purposes. Any substantial or systematic reproduction, redistribution, reselling, loan, sub-licensing, systematic supply, or distribution in any form to anyone is expressly forbidden. Terms \& Conditions of access and use can be found at http://www.tandfonline.com/page/termsand-conditions 


\title{
Followership and leadership in different sorts of sloyd practices
}

\author{
Marcus Samuelsson* \\ Department of Behavioural Science and Learning, Linköping University, Linköping, Sweden
}

\begin{abstract}
This study examined the extent to which students fully embrace sloyd activities. Sloyd is a form of adventurous education in Sweden where school students take more control of the content and methods of learning as part of their weekly education. Hands on activities are often part of the adventure and it sometimes takes place outdoors. The study focused on two sloyd groups, one led by their school teacher in school time and one group who volunteered for sloyd out of school hours. Students in the school context were expected to follow the sloyd teacher's instructions and they were supposed to choose between an individual task or a group assignment at the beginning of the semester. The youngsters in the sloyd club context were expected to manage the sloyd activities themselves as and when they attended the voluntary sessions. That children and young people embrace sloyd is more or less taken for granted, whether it is part of students' school activities or youngsters' spare time activities. However, we found there was a variation in the extent to which students embraced sloyd from both the class based and voluntary groups. The class-based students' willingness to embrace sloyd depended on whether their activity assigned to them by the teacher was interesting to them. Although the out of school students voluntarily chose their activity, some of them still declined to embrace fully the sloyd approach due to a general lack of interest in the activities. Our conclusion is that sloyd leaders or facilitators need to consider individual differences to ensure sloyd is fully embraced.
\end{abstract}

Keywords: followership; leadership; sloyd club; school sloyd; Yo-yo fieldwork

\section{Introduction}

In the mid-1990s, sloyd was established as part of a non-governmental movement for children and youth by the regional Östergötland Handisloyd Council in Sweden. It was an idea about giving children and youth opportunities to take part in sloyd activities in their spare time (Nämnden för hemslöjdsfrägor 1998). Sloyd activities arranged by The National Swedish Handisloyd Council expanded during the first 10 years of the twenty-first century (Sohlberg and Boström 2010). Sloyd or Crafts is now a subject in the Swedish compulsory school where students are supposed to train their ways of thinking and express themselves using tools to produce objects and processing materials (Skolverket 2011).

As part of the National evaluation of the Swedish compulsory school 1992, NU-92 (Skolverket 1993), and 2003, NU-03 (Skolverket 2005), students responded to questionnaires regarding their experiences of sloyd as a school subject. The students who participated in NU-92 and NU-03 found sloyd to be one of the most interesting and joyful subjects in school. They mentioned that during sloyd lessons, they were

*Email: marcus.samuelsson@liu.se 
given opportunities to take initiatives and to be responsible for their own work. They were also given lots of influence during sloyd lessons. At the same time, they claimed that they did not understand how the things they learnt in sloyd could be useful or important in the future (Skolverket 2005).

Swedish children and youth could thereby be described as enjoying sloyd activities in school as well as in sloyd out of school clubs. It therefore seems reasonable to examine what it means to actually embrace an activity such as sloyd in the different contexts of school time and out of school time. Could 'embrace' mean one thing in relation to school sloyd and something else in relation to sloyd clubs? Could 'embrace' be related to leadership or followership? Could it be linked to actual influence during the activities? Until now, we have few answers to such questions. This article therefore aims to contribute with some answers by problematising what five students in a Swedish school sloyd practice and seven youngsters in a Swedish sloyd club practice experienced during a semester.

\section{School sloyd for children}

School sloyd does not exist in every school system in the world, or, to be more accurate, it exists in very few school systems beside the Nordic countries. There are certain differences between the Nordic countries as well. The same is true when it comes to sloyd clubs, which only exist in Sweden. For such reasons, this article is delimited to earlier research and evaluations conducted in Sweden.

Swedish research on sloyd in general and pedagogical sloyd in particular has been limited. Pedagogical dissertations by Borg (2002), Johansson (2002), Hasselskog (2010) and Mäkelä (2001) in the first decade of the twenty-first century came to alter this picture somewhat.

Borg (2002) interviewed former students about their impression of school sloyd. Some informants remembered their sloyd teachers because they had listened to them, had been inspiring and a good classroom manager. Other former students remembered their sloyd teachers because they had been odd, strict or difficult to understand. It was obvious that the former students appreciated skilled and nice sloyd teachers. Based on what these former students thought about their sloyd teachers, Borg concluded that there were four different types of students: expressive, curious, obedient and uninterested. According to Borg, the expressive students worked creatively and made unique personal items, whereas the curious students were investigative when solving a problem in order to make things work. Borg also described that the obedient students worked according to instructions and tips from the teacher with an agreed product, whereas the uninterested students needed support from the teacher in order to complete even limited and simple tasks because they lacked intention for sloyd.

Johansson (2002) made observations in order to describe activities in the comprehensive school. She particularly studied what and how students did while they had sloyd, as well as how sloyd was described by students, teachers and parents/ guardians. Johansson's results show, among other things, that work in sloyd revolves around verbal and non-verbal interaction, and that the teacher in large part gives instructions that the student follows. Dialogues that challenge and deepen the students' understanding were less common. It was more common that the teacher 
guides the students through certain phases. In connection with this, the activity was adapted to the students' varying abilities.

By studying sloyd teacher diaries, Hasselskog (2010) found four different ideal types of teachers: the Serviceman, the Instructor, the Mentor and the Pedagogue. There were some clear differences in the approach of these ideal types. The Serviceman helped the students with what they needed or wanted based on their professional knowledge, while, to avoid errors, the Instructor demonstrated what was to be done. The Mentor used different methods, together with the students, to drive the work forward, as apart from the Pedagogue, who directed him- or herself towards the students' understanding with instructions and questions.

Mäkelä (2001) observed, communicated through the web, and interviewed secondary school students in order to seek answers about their experiences of sloyd. He found that objects made in school sloyd were important to some of the students. They were proud of their sloyd objects, while others had hidden or even thrown their sloyd objects away. The students' answers reflected in all cases their feelings about sloyd as a school subject.

To summarise, Borg (2002), Johansson (2002), Hasselskog (2010) and Mäkelä (2001) have described that students experience sloyd in school in different ways. This is not surprising. Nevertheless, it is important to describe and discuss students' experiences of school sloyd. The researchers mentioned above have shown that students' experiences vary in relation to who they are and who their classmates are. It also depends on who their sloyd teacher is and how the teacher has interpreted the syllabus and planned the lessons. Connected to this is the aspect whether or not the students feel that they have any actual influence on the process or how involved they are. Whether or not the students' family and social context are involved also seems to matter in some cases.

\section{Sloyd clubs for children}

In the 1998 report of The National Swedish Handisloyd Council, youngsters' engagement in sloyd activities arranged by the handisloyd movement was described for the first time. Some interviewed youngsters indicate freedom as their motive for taking part in handisloyd activities. The lack of a teacher is emphasised as a particular aspect of freedom. The sloyd clubs have leaders instead: 'Mentors who guide and help you on the basis of your own abilities' (Nämnden för hemslöjdsfrägor 1998, 36). Calmness and the capacity to go in for the work are put forward as valuable qualities for enjoying an activity where: 'There is a different restfulness than in school, that's pleasant' (Nämnden för hemslöjdsfrägor 1998, 36). The national handisloyd consultant for children and young people, who was appointed when the activities were established in Östergötland, argues that everybody should be able to participate in the handisloyd movement activities for children and young people because all children and youngsters enjoy working with sloyd. In the efforts to reach everybody, she argues, new unconstrained thinking is required. The handisloyd movement must not fall into traditional traps:

We must take care not to be didactical in our eagerness to get others to understand, it could easily lead to our being more school-like than the school itself has ever been. Traditional handisloyd has never been teacher-centred; their knowledge has been passed 
on in a way that resembles the little child's way of learning: observation, attention, imitating 'do-it-yourself'. (Nämnden för hemslöjdsfrägor 1998, 11)

The national consultant refers to Mead's theory of post-, co- and pre-figurative cultures. The consultant focuses especially on the last-mentioned, which in Mead's terms (1970) is presented as 'children learn from their coevals'. The consultant interprets this as 'The grown-up's attention is drawn to the fact that here there is something to learn, something that belongs in our culture' (Nämnden för hemslöjdsfrägor 1998, 11).

\section{Fieldwork}

The idea of field research - to be present here and now, 'Studying at firsthand what people do and say in particular contexts' (Hammersley 2006, 4) - still carries weight. But the traditional notion of year-long fieldwork has been put in question by Barth (1994) and perhaps even more by present-day Swedish anthropologists who argue that 'One hardly needs, for example, to be present during all seasons, for the simple reason that seasonal change does not mean so much for the ideas, activities and relations one is interested in' (Hannerz 2001, 23).

The localisation aspect of traditional fieldwork is thereby called into question by Hannerz (2001), who argues for a changed approach, where several fields in one give the researcher different points of observation for understanding a phenomenon. In my case, I spent half a year in two sloyd practices, one a comprehensive school's wood- and metalwork class, and the other a sloyd club at one of Sweden's county handisloyd societies, in order to get to know people and understand the contexts. Data were gathered as two parts of a Yo-yo fieldwork (Wulff 2002). As Wulff (2002) suggests, I was stationed in the immediate environment of the sloyd practices being studied, doing observations, writing field notes and, in some cases, working side-byside with the youths in the sloyd club as a way to get them to see that I knew how to actually handle tools and materials. In that way, I could shuttle between close fieldwork sessions and more distant writing and reflection sessions. The alternation between the sloyd club context and the school sloyd context also gave me a foundation for comparisons of and reflections over what I observed in the two sloyd groups. Permission to follow the practical sessions had been preceded by a visit where I explained my interest in the intended study and my background as a teacher of wood- and metalwork and also a woodworker. Thus, I moved in and out of these two practices, week after week for half a year, i.e. one semester (Hannerz 2001). Initially, I sat or walked around during the practical sessions, made open observations and wrote visible field notes. 'As a participatory observer you will rather study what activities people themselves start up, who is present, what profiles and positions they have and what they say, without necessarily asking them questions' (Fangen 2006, 33). I tried to be open and inquisitive (Geertz 1973) and write about the interactions between adults and children or youngsters. I tried to register routines and rituals, and pay attention to critical events. I also made lists of tools, machines, materials and posters or signboards, and chatted with the students and youngsters as well as the adults before, during and after the sloyd activities.

At the end of the fieldwork, I conducted individual, recorded interviews with the five students I had observed in the school sloyd sessions and the seven youngsters 
I had observed in the sloyd club sessions. This meant that all youngsters who worked in the wood and metal part of the sloyd club were interviewed. As for the school sloyd practice, I interviewed three single students and one pair of students who worked together at the beginning of the semester. They were chosen based on one how they behaved, argued and interacted with the teacher during the first lesson, as well as where they were placed in the wood and metal classroom. The interviews were directed towards how the students and youngsters had experienced the sloyd activities in general and what experiences it had offered them.

The collected empirical observations are interpreted in different ways. In what by Fangen (2006) is spoken of as first-degree interpretation, what I had seen and heard during the fieldwork was established, often in close proximity to the work sessions in the field. This groundwork then formed a basis for the second-degree interpretations, attempts to go beyond the everyday and the sometimes taken-for-granted notions of what happens in sloyd training. I returned to the field notes and interviews and became more familiar with the empirical observations alongside with reading various studies of unconnected practitioners with the aim of letting theory and practice surprise each other (Willis and Trondman 2000). The result of this dialectical approach enabled third-degree interpretations, attempts to reflect critically on the self-awareness of the participants in the sloyd practices. This is described by Bjurström $(2004,93)$ as 'partly empathetically entering into the lived culture of people, partly seeing through it'. This ambition lies at the heart of the results of the present article.

\section{Being part of sloyd practices}

From my own prior knowledge, I had the impression that sloyd practices could appear in various forms. This meant that during the fieldwork, I repeatedly registered and discussed aspects of the respective sloyd practices. These observations and conversations revealed differentiating factors.

The school sloyd practice appeared dutifully productive, unlike the sloyd club practice where conditioned improductivity reigned. Another factor was that students in school sloyd were restricted by the general economic grant of the school for sloyd and specific allocations between sloyd teachers and course years, whereas the youngsters in the sloyd club group paid for the material they used. Yet another difference was that the sloyd club was regularly visited by inspirers, sloyd people with special skills, whereas in the school sloyd classes, the sloyd teacher and I were the only adults. The planning of the school sloyd sessions proceeded from the sloyd teacher's professional training and interpretation of the current curriculum, in contrast to the sloyd club sessions, which were governed by an activity council with young people in the majority. The purpose, the goal to strive for, or the objectives to reach in school sloyd differed markedly from the sloyd club, where participation could be seen as the purpose. The difference in time available between the two forms of training was also a factor. Table 1 does not show effective time for sloyd work but includes start and finish for both varieties and a 30-minute break for the sloyd club sessions. Furthermore, in the school sloyd group, all students were of the same age, whereas the sloyd club group was heterogeneous. This meant that in the club sessions, it was possible to integrate different ages in a way impossible for the school groups. This irrespective of the degree of sloyd skills, development, interest or motivation, is diverged between the youngsters and the students in the two sloyd practices. 
Table 1. Differentiating factors between school sloyd training and sloyd club training.

\begin{tabular}{lll}
\hline Factors & School sloyd training & Sloyd club training \\
\hline Activity & Mandatory & Voluntary \\
No. of participants & 13 pupils & 7 youngsters \\
Economy & Grant & Cost price \\
Inspirers & Sloyd teachers/pupils & Guests/young people \\
Character & Obligatory & Voluntary \\
Leader & Trained sloyd teacher & Aircraft engineer \\
Locale & School sloyd workshop & Homecraft location \\
Timing & Schooltime & Free time \\
Planning & Sloyd teacher & Activity committee \\
Aim & Target achievement & Participation \\
Tid & 80 minutes & 180 minutes \\
Age & 11 & $11-20$ \\
\hline
\end{tabular}

\section{Teaching materials in the two sloyd practices}

From earlier experience, I knew that teaching materials for sloyd, such as books, magazines, templates, drawings and sketches, have existed since Swedish school sloyd grew strong, even measured by international standards, with the instruction that preceded that in Östergötland. I knew, too, that computers and various kinds of computer programs as teaching material, although most commonly in connection with textile handisloyd, had been established in school sloyd since the 1990s. Given this knowledge as a background, I conducted direct search for different kinds of teaching material in sloyd training and discovered that on the whole there was none to be studied. This applied both to printed material and computers. Exceptions were some notices and signs.

The short text presented in Figure 1 was posted on the inside of a door in a tool cupboard containing cutting-edged tools for shaping wood and other tools for woodwork. The text, as I interpret it in its context, enjoins the sloyd workers not to

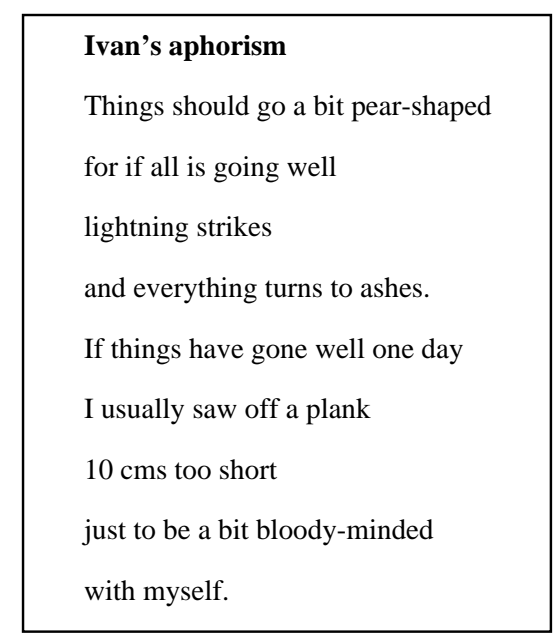

Figure 1. Aphorism by Bengt Cidden Andersson (Hassler 1992). 
take wood-working for granted, to be humble in the face of the limitations imposed by body, materials and tools, and, further, not to be too 'cocky' over the results of one's own handiwork. It expressed a sort of reflective approach, which I understood to characterise sloyd club training. In both sloyd practices, there were also other notices which gave instructions as to how the participants should act when painting or surface treatment was carried out. The notices instructed that protective clothing should be worn, that the workshop should be kept clean and tidy, which meant tidying away paints and washing brushes. It also meant having a protective covering so that the surface treatment did not stick to the paint bench.

Apart from this text, both workshops contained different kinds of signs, yellow with a red border in a colour clearly resembling the warning signs of vehicular traffic or blue signs with a white border resembling traffic information signs. The yellowand-red warning signs prescribed special rules and restrictions which applied when a particular job was being done, for example in the smithy, or if a special approach was required when a particular machine, lathe or pillar drill was used. The blue-andwhite information signs prescribed the use of earmuffs and protective glasses on a specific level in connection with machine-tool work or generally in sloyd work. The difference between protective and information signs and posters was partly a matter of the prohibitive or educative character of the signs, which in the first case were concerned with the students' life and health, something irreplaceable, as apart from the admonitory approach in the signs, concerned with the students' possessions and clothing, things for the most part replaceable. But the signs also dealt with taking responsibility for each other, by, for example, making it possible to paint with fresh paints, resilient brushes and daub-free protective paper. Both notices and posters were in the two sloyd workshops.

\section{Describe framework or ask for wishes}

The first occasion in both sloyd classes began with various polite phrases from the responsible adults. The attendance of the participants was noted and hopes expressed for the sloyd meetings during the forthcoming term. So far the sloyd practices resembled each other. When the course content was then introduced, the adults responsible for the respective courses went about it in quite different ways. The sloyd teacher made a convergent introduction which focused on a restricted goal. This restriction, and in a way the reduced variation, can be understood in relation to the prescribed current aspirational attainment goals. Thus, the curriculum provided the frame for the sloyd classes. The divergent introduction which the children and youngsters' advisor in the sloyd club used focused on an unrestricted goal. This openness, and in a way maximised variation, can be understood in relation to the voluntary nature of participation in the sloyd club practice. In that way, the liberty of choice framed the sloyd club activity (Figure 2).

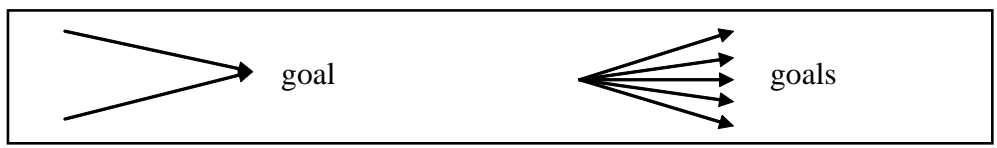

Figure 2. Convergent (school sloyd) or divergent (sloyd club) introduction. 
In connection with the convergent introduction, the sloyd teacher pointed out that in school year 5, students were faced with a choice:

\begin{abstract}
'A box with lid and lock or group work to decorate the school'. He continued by saying: 'The size of the box is fixed at $30 \mathrm{~cm}$ maximum'. The motive for this, when one of the students wondered, was given as 'Because big ones don't turn out very well'. When the student said nothing more, the teacher continued and described how the box should be drawn on A4 paper: 'From above, from the front and from the side'. He indicated a sheet of white A4 and looked up at the students, who seemed to be following his briefing. He backed away from the paper, again looked at the students and said: 'If necessary I'm here. And if you haven't got any ideas, I'm here. I don't like it if you all do the same, your own ideas, your imagination about size and decoration should rule. Fetch boards now'. (Field note, 23 August)
\end{abstract}

The sloyd teacher thus exhorted the students, based on the prescribed framework, to construct something that bore traces of themselves, and at the same time, by asking them to fetch wood, he indicated another limitation as regards the material to be worked on, in the form of deal boards, and relative to the dimensions available in the wood store. An introduction like this could be understood as the teacher trying to make the students feel as if they had some influence (Skolverket 1993, 2005). The sloyd teacher thereby underlined that each of the students was expected to decide what he or she should do, and set about their individual work. This could be understood as an idea of the students making personal objects (Mäkelä 2001).

The sloyd club advisor's divergent introduction drew the youngsters' attention to the objects on the table around which they gathered on the first occasion of the term, handmade cloth bags in many different colours and patterns, woven placemats, toys, hand-carved spoons, rope work, chiselled troughs, leather and leatherwork, knitted products, turned objects, birch bark work, tanned fish skin, as well as trimmed and untrimmed lambskin, all to be seen as examples of what could be done during the coming term. The advisor then urged the young people to write down their wishes on the A4 paper in front of them, and pointed out that these wishes would form the basis of the term's activity. She also hinted that not everybody's wishes were possible to fulfil directly, during the coming term, but also that it perhaps might not be possible at a later date either, among other things in view of the possibility to find a suitable inspirer: 'The evening will be devoted to an inventory of requirements and what you hope to take away from here' (Field note, 4 September). The advisor pointed out on the second occasion that the youngsters were expected: "not to do the same as him [the inspirer], you must come up with your own ideas' (Field note, 11 September). The youngsters were encouraged by statements of this kind to contribute to the collective, to expand everybody's ideas of a conceivable content for the sloyd club's activities. Through introductions and options like these, the sloyd clubs made it clear that this was something else than school sloyd (Nämnden för hemslöjdsfrägor 1998).

\title{
Head-on or feel your way
}

After the introductions from the sloyd teacher or an inspirer, how the participants, students and youngsters, went about their work differed both between and within the two sloyd practices. General differences between the two types of practice became clear in that the students in the sloyd class kept to what appeared to be a linear 
planning introduced earlier, while the sloyd club group related to an established figurative planning (Figure 3).

In the school sloyd context, all students were urged to make their boxes in a particular order, step by step according to a linear plan. This particular order was not problematised, but seemed preordained, and was strengthened by the specific briefings which at irregular intervals interrupted or punctuated the sloyd lessons.

The teacher introduced the particular working procedure: (1) choose material, (2) cut material, (3) plane the material and (4) shock plane the material. When doing this, he very much acted as the ideal type instructor described by Hasselskog (2010). The sloyd teacher pointed out to the whole class that if a student was physically absent, or temporarily inattentive, a poster with the order of working which had been introduced, section by section, would be accessible and visible in the workroom during the following lessons. Another expression of the linear planning was the reviews, which in a pre-emptive manner explained possible problems in the form of techniques, stages and aids that the students would come to deal with. The reviews were exclusively directed at the production of boxes, but the few students who had chosen decoration of the school instead of making a box (see field note, 23 August) also took part without comment in the reviews. The sloyd teacher's way of working seems very much like the sloyd teacher Johansson (2002) described as highly structured. Another similarity is the importance of interaction between the students and the sloyd teacher in order to stick to the plan.

The linear planning also constituted a basis for discussion between the sloyd teacher and the student in that the teacher repeatedly asked to see, and exhorted the student to relate to, the sketch made at the beginning of term. In this way, the importance of the stage and direction was confirmed. The dignity of the work procedure became obvious in a conversation between a boy and the sloyd teacher:

'I don't see your sketch?' The boy and the teacher looked for it and found it under a board on the boy's workbench. The teacher looked at the sketch and then at the board before asking: 'Have you planed this down?' The boy answered: 'No, it fitted perfectly in height'. The teacher muttered and then asked: 'Have you planed anything new?' The boy answered tersely no. The teacher continued: 'Then I think you've got off a bit too lightly, the idea was that you should do some planing'. The boy looked at the teacher without saying anything. The teacher continued: 'Now I'll make higher demands on you for the bottom and the lid, now I think you should do something fine with the lid'. When the boy didn't reply, the teacher left him and went to another student. (Field note, 23 August)

Discussions like the above were also a check as to what the students had understood from the individual reviews and what part the reviews played in the whole process.

The work in the sloyd club practice appeared as individual figurative planning where the youngster sketched, selected, presented, revised and re-presented their

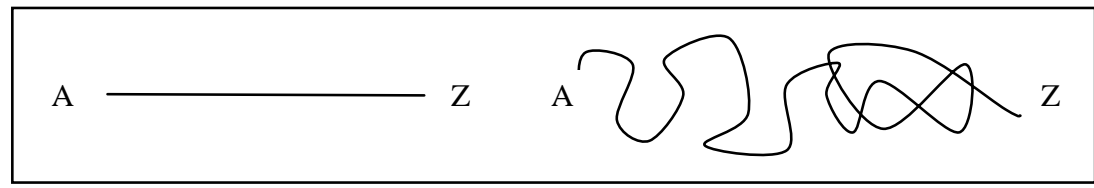

Figure 3. Linear or figurative planning. 
different projects. In that way, the common principle found in the school practice was absent:

One of the sloyd club's girls sought out the mentor and said: 'Do you know what, now I know what I want to make, a stand I can dry apples on. With some sort of groove under in case they should fall down'. The mentor answered: 'Smart, now give us a few measurements so we know how big a plank we need'. The girl smiled in reply and went her way. (Field note, 11 September)

Based on the sketch the girl had made, they discussed her forthcoming work. The girl came back soon after and then wanted to make a bentwood box, big enough for large round crisp bread. The mentor once again asked for a sketch and her experience of making bentwood boxes before they together observed others' work in progress on bentwood items. The use of figurative planning did not appear problematised but seemed to follow the sloyd club's motto of being something different from school sloyd (Nämnden för hemslöjdsfrägor 1998). It could perhaps also be understood in the light of an interpretation of Mead's (1970) idea of pre-figurative cultures where the youngsters learn from each other. Such an interpretation is also supported by the mentor's expression when speaking with me: 'I don't have any pedagogical training but love to be with young people' (Field conversation, 23 October). Whether or not the young people were attentive during the inspirer's reviews or when they were given coaching appeared to be of lesser importance, not least because they owned their projects and the speed at which they were carried out.

Beside these general points, there was also a gender difference in that the boys in both groups began the sloyd activity more directly than the girls, who appeared more hesitant and several times reappraised and changed their minds about what they were interested in making. 'Girls measure first and cut afterwards, while boys do the opposite, they are a little tougher and often have to redo the job' (Field note, 11 September). The mentor's experience was confirmed a little later during the term when a boy in his delight at hewing troughs chopped through the bottom so that a hole appeared. The boy answered the mentor's question what he had learned from the error:

'To take it a little easier next time, but the hole really doesn't matter'. The mentor looked a little quizzical and the boy continued: 'It was so much fun chopping' (Field note, 30 October)

In this way, the boy offset the mentor's exhortation to circumspection while at the same time defending his right to get carried away by the zestful carpentry.

\section{Determined, neutral or undecided participants}

In both practices, there were students and youngsters who in different ways went in for the sloyd activities. In the school sloyd as well as in the sloyd club group, there were students and youngsters who were decided about the point of participating in the practices. Alongside them were both students and young people who were neutral about the point of taking part in the two sloyd activities. A third way to express the point of taking part was to be found among the undecided. These three categories 
corresponded, to some extent, to Borg's (2002) findings of four different sorts of sloyd pupils.

The decided students and youngsters, the expressive pupils according to Borg (2002), appeared purposeful. They had clear ideas, were communicative with the grown-ups and behaved with some sort of rationality in their choice of products, tools and processes. These students took part reluctantly during the reviews in the school sloyd lessons, waiting to be allowed to get on with their own work. The youngsters in this category seemed to carefully select or reject the inspirers who visited the sloyd club activities. The decided students and youngsters described in detail the objects they had planned, worked on and completed during the term when they were interviewed. One boy from the school sloyd group said: 'My box turned out exactly as I thought. My father will hopefully be happy when he gets it as a Christmas present'. Other students as well as youngsters appeared to make use of the process as a way to complete products that bore traces of their own personal deliberations.

The neutral students and youngsters, the obedient pupils in Borg's terms (2002), considered in a different way what they would do, they seemed to need the adults' exhortations to fetch tools and carry out operations. These students seldom tried to negotiate what could be done in the school sloyd practice. Their negotiations concerned choice of work, group work or the size of a box:

One of the girls in the class said straight after the introduction when she had decided to make an individual task, a box, that: 'I want to make a horse chest that is two metres long'. The sloyd teacher looked at her and replied that: 'A horse chest of two metres would cost 500, and if you were allowed to make something bigger, someone else would ask why she was allowed to'. (Field note, 23 August)

The teacher answered the student's bid as the above excerpt shows. The neutral students' attempts at negotiation did not appear to bring any changes. The responses they received encompassed few other possibilities than to re-think and thus approach what the sloyd teacher had intended. The same girl answered during the interview to the question 'What have you learnt during this semester in the sloyd':

I can't describe what I have learnt during the school sloyd term, actually I don't know if I have learnt anything at all. (Interview, 28 November)

Like other neutral students, she could to a lesser degree specify what she would use her object for. It, thereby, seemed that the link between the school content and life outside school, which Johansson (2002) as well as Mäkelä (2001) point out as important, was missing according to these students' experiences. The neutral youngsters appeared to benefit actively from the inspirers' assistance and tried out many different sloyd techniques during the term. In that way, they started on several different processes and products but finished very few. It seemed as if they were carried away by an enthusiastic inspirer and this resulted in a new piece of carpentry being begun.

Analogous features were also to be found in the undecided students and youngsters, the uninterested pupils (Borg 2002). They were students or young people who seemed unwilling to pursue projects of their own and expressed a lack of interest in sloyd. The undecided students were noticed by the sloyd teacher when they repeatedly had not made any progress or lacked parts of the work, were too inactive, 
or paid inadequate attention to reviews. One boy's passivity was noticed and the teacher asked: 'Do you want an extra job to do while you're waiting?' (Field note, 3 October). The boy answered yes and was given a sawn-out piece of juniper to make into a key tab. The teacher had earlier in the term spoken with the same boy and pointed out that:

You must try, you must get a hold on this now, make an effort, and it mustn't be like what happened with the bowl when you said 'if I can only do this at home...'

The boy didn't answer, so the teacher left him at his workbench. (Field note, 23 August)

He worked, like other undecided students, with so little effort that the sloyd teacher spoke with him and argued for the idea of working as part of the sloyd subject like any other school subject. Another way to understand such incidents could be that the students were forced to accept a certain way of working while finding themselves denied actual influence or the chance to lead their own learning process, in direct opposition to earlier sloyd research (Borg 2002, Johansson 2002, Hasselskog 2010, Mäkelä 2001).

In the sloyd club group, there were young people who appeared undecided. These youngsters spent most of the time talking or walking around. They also indicated, in conversation and without being asked, that 'I'm here because my girl-friend is here', or 'I'm here because my parents want me to be here'. Neither process nor product appeared to attract these uncertain students or youngsters.

\section{Concluding remarks}

Students' and youngsters' experiences of liking sloyd, in school or at clubs, could be understood as them being forced to take on to different kinds or roads, in a metaphorical sense. They had to follow or lead their way on a big highway with several lanes or on to a smaller country road. By the use of such a metaphor, the school sloyd could be described as a straight highway where the students were supposed to transport themselves from one position to another during a semester. The sloyd teacher had decided what highway the students were to follow as well as where the slip road started and what goal they had to reach. The sloyd club could, on the other side, be described as a winding country road with lots of crossroads and places for short stops. The advisor as well as the mentor requested that the youngsters looked for their own road. Finding and finally following their road also meant that the youngsters could turn off into some of the crossroads they passed through during the semester. It also meant that they could stop at some of the halting places or vantage points, for as long as they wanted.

When the students were supposed to develop skills, the youngsters were supposed to find perspectives. This was also a consequence of the fact that the school sloyd group had a syllabus to follow, while those in charge of the sloyd club only had to make sure that the youngsters stayed in the club instead of being somewhere else. According to speed, the students were restricted to follow speed limits. When working too fast, they were brought into a sort of speed check-up by the sloyd teacher. When working too slowly, they were forced to speed up. The students were to figure out and go along with the sloyd teacher's ideas of reasonable speed. Ideas of speed were also 
found in the sloyd club when some of the youngsters worked too fast or drove off the road, finding the mentor asking what they learnt from their mistake. Working too slowly was not a problem in the sloyd club. The students' and youngsters' experiences of being allowed or forced to drive was yet another aspect of how much they embraced sloyd. Some of them embraced to sit in the driver's seat, while others embraced to be the co-driver less in charge. Some were allowed to choose while others were forced to accept a certain role, whether they embraced it or not.

Permission to choose and re-choose between leading or following, and being allowed to choose what road to follow and what speed to use seemed equally important for the experience of liking sloyd despite which sloyd practice they were a part of.

\section{References}

Barth, F. 1994. Manifestasjon og prosess [Manifestation and Process]. Oslo: Universitetsforlaget.

Borg, K. 2002. Slöjdämnet: Intryck - avtryck - uttryck [Arts and Crafts as School Subject (Slöjd) Impression - Expression - Imprint]. Linköping: Linköpings universitet.

Bjurström, E. 2004. "Hermeneutisk etnografi. Tolkningens plats i det etnografiska arbetet. I L. Gemzöe (red.) [Hermeneuthical Ethnograpy. The Place for Interpretation in Ethnographic Work]." In Nutida etnografi: Reflektioner om mediakonsumtionens plats [Contemporary Ethnography: Reflections on Media Consumption and Space], 73-95. Nora: Nya Doxa.

Fangen, K. 2006. Deltagande Observation [Participation Observation]. Stockholm: Liber.

Geertz, C. 1973. The Interpretation of Cultures. New York: Basic Books.

Hasselskog, P. 2010. Slöjdlärares förhållningssätt i undervisningen [Strategies of Teaching Sloyd in the Classroom]. Göteborg: Göteborgs universitet.

Hammersley, M. 2006. "Ethnography: Problems and Prospects." Ethnography and Education 1 (1): 3-14. doi:10.1080/17457820500512697.

Hannerz, U. 2001. "Introduktion: När fältet blir translokalt. I: U. Hannerz, (red.)." In Flera fält $i$ ett: Socialantropologer om translokala fältstudier [Several Fields in One: Social Anthropologists About Trans-Local Field Studies], 7-35. Stockholm: Carlssons bokförlag.

Hassler, G. 1992. Den nyaste ordmusiken: En antologi [The Newest Wordmusic: An Anthology]. Stockholm: En bok för alla.

Johansson, M. 2002. Slöjdpraktik i skolan - hand, tanke, kommunikation och andra medierande redskap [Craft and Design in School - Hand, Mind, Communication and Other Mediating Tools]. Göteborg: Göteborgs universitet.

Mead, M. 1970. Kultur och engagemang: En studie av generationsklyftan [Culture and Commitment: A Study of the Generation Gap]. Stockholm: Rabén gren.

Mäkelä, E. 2001. Slöjd som berättelse: Om skolungdom och estetiska perspektiv [Slöjd as Narrative - On Schoolchildren and Aesthetic Perspectives]. Umeå: Umeå universitet.

Nämnden för hemslöjdsfrågor. 1998. Visa mig! Ungt möte med slöjd [Show me! Young Meeting with Crafts]. Stockholm: Nämnden för hemslöjdsfrågor.

Skolverket. 1993. Slöjd. Huvudrapport. Skolverkets rapportserie $n r 24$ [Craft. Main Report. National Agency for Education Report Series No 24]. Stockholm: Liber distribution.

Skolverket. 2005. Nationella utvärderingen av grundskolan 2003: Ämnesrapport Slöjd [National Evaluation of Elementary School 2003: Topic Report Crafts]. Stockholm: Fritzes.

Skolverket. 2011. Curriculum for the Compulsory School, Preschool Class and Leisure-Time Centre 2011. Stockholm: Skolverket.

Sohlberg, A., and K. Boström. 2010. Slöjdklubben: Röster från verksamheten [Craft Club: Voices from the Activity]. Stockholm: Hemslöjdens förlag.

Willis, P., and M. Trondman. 2000. "Manifesto for Ethnography." Ethnography 1 (1): 5-16. doi: $10.1177 / 14661380022230679$.

Wulff, H. 2002. "Yo-yo Fieldwork: Mobility and Time in a Multi-local Study of Dance in Ireland." Anthropological Journal of European Cultures 11 (1): 117-136. 